\title{
5. How neglecting policy mechanisms can lead to policy failure: insights from public-private partnerships in India's health sector
}

Altaf Virani and M Ramesh ${ }^{1}$

\section{PUBLIC-PRIVATE PARTNERSHIPS AS POLICY INSTRUMENTS}

Public-private partnerships (PPPs) have emerged as popular instruments for delivering public services to citizens. Functions that governments were formerly expected to fulfil are increasingly being passed on to the private sector to operationalize the public mandate. PPPs serve as vehicles for such transfer of functions. They are essentially medium- or long-term arrangements between the government and private agencies for the development of public infrastructure or the provision of public services by the private sector with clear agreement on shared objectives (World Bank Group, 2014). They can exist in a range of sectors, each subject to different legal, regulatory and investment considerations, and can assume a variety of forms with varying degrees of involvement of the private partner.

Proponents of PPPs have argued that traditional organization of public services is often and increasingly inefficient and ineffective. Governments, especially in developing countries, lack the capacity to deliver good public infrastructure and services. Weak governance institutions and practices, poor information and performance measurement systems and weak accountability arrangements have been identified as hurdles to the success of large-scale public provisioning of goods and services (Fritzen, 2007). It is argued that the introduction of professional private sector management can potentially infuse efficiency and productivity in the management of public works and services, and enhance the ability of governments to effectively deliver on their civic responsibilities (Borins, 1995). In the healthcare sector, contracting out of health services to private providers has been found to boost performance in 
terms of higher outputs, widen the range of services and improve the quality of healthcare provided (Lönnroth, Uplekar and Blanc, 2006; Liu, Hotchkiss and Bose, 2008; Bisht and Virani, 2016).

Critics, however, have pointed to the drawbacks of PPPs, particularly in social policy. Mills (1998) and Liu et al. (2008) find that PPPs lower the costs of production for the private provider, but have questionable effects on overall costs of service provision for the government. They have also been known to suffer from poor transparency and democratic accountability, and grievous issues arising out of poorly designed contracts (Daniels and Trebilcock, 1996; Boase, 2000; Morgan and Campbell, 2011). PPPs have blurred the boundaries between the market and the state. This fragmentation of role and authority has had serious ramifications for the comprehensiveness of services provided by the government, the governance of such services and their accountability to citizens (Baru and Nundy, 2008). Governments are accountable to citizens in ways the private sector is not and cannot abnegate their responsibility to protect their citizens (Moe, 1994). There are also economic arguments for why the provision of public goods (and the ownership of public assets) should rest with the government, especially in matters that are central to the government's mandate, and where the private sector has few shared objectives (Besley and Ghatak, 2001; Hart, 2003; De Bettignies and Ross, 2004; Iossa and Martimort, 2015).

Nevertheless, PPPs are legitimate albeit contentious instruments of public policy. Their efficacy depends on their design and deployment in promotion of public interest. In this chapter, we explain how approaching PPP design from a mechanism-based perspective promotes more effective PPP interventions. We consider issues of policy coherence, contract design, policy capacity and regulation that affect the nature of the interactions that are triggered by PPPs. We then examine these issues in the context of the policy framework for healthcare PPPs in India and the experience of three partnership projects. Based on this review, we identify common design failures that need to be addressed to make PPPs more effective. We argue that the failure of PPPs is essentially a consequence of weak design that stems from poor understanding of the conditions that are required to make them work. Recognizing the causal pathways involved in how PPPs produce their effects is crucial for instituting design features that can lead them to be successful.

\section{A MECHANISTIC APPROACH TO PARTNERSHIP DESIGN}

The aim of policy design is to develop effective policy solutions that can potentially address the problem at hand in a given socio-political context. The task is inherently multifaceted and involves a multistep problem-centred approach (Figure 5.1). 


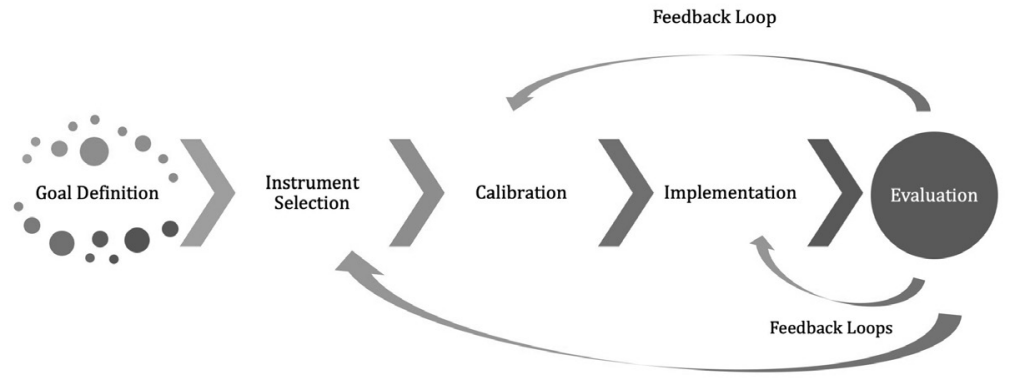

Figure 5.1 The policy design process

The key is to identify what end-state one wants to achieve, and reverse engineer a design that can potentially lead to the achievement of that end-state (Maskin, 2008). Because policy mechanisms constitute the processes through which policies produce their effects, policy failure can be construed as failure to discern and leverage key mechanisms to inform the selection and deployment of instruments that can facilitate or nudge actors to behave in ways that are conducive to the achievement of overarching policy goals.

The policy design process entails a careful consideration of the following questions:

- What is the nature, extent and root cause of the policy problem to be tackled?

- What would a satisfactory resolution look like?

- What are the tools available to the policy-maker to deal with the problem?

- How does a given instrument affect change?

- What is the cost-benefit calculus?

- How effectively can the instrument be deployed?

- To what extent can contextual economic and political variables be purposively manipulated to enhance effectiveness?

- Based on these considerations, which is the instrument best suited to resolve the problem in a given context?

- How would one determine policy success or failure?

- How would evaluation results affect next steps in terms of policy continuation, course correction or termination?

These same questions are relevant to PPPs. In practice, however, their use is often based on misconceptions about the capabilities and limitations of the instrument. There is a tendency to prescribe them as a universal remedy for government failure, without attention to the conditions required for making them work. While they are politically attractive solutions in the short term, their complexity and long tenure make it difficult to ensure their designs are effective (Vining and Weimer, 2016). A piecemeal approach would yield no 


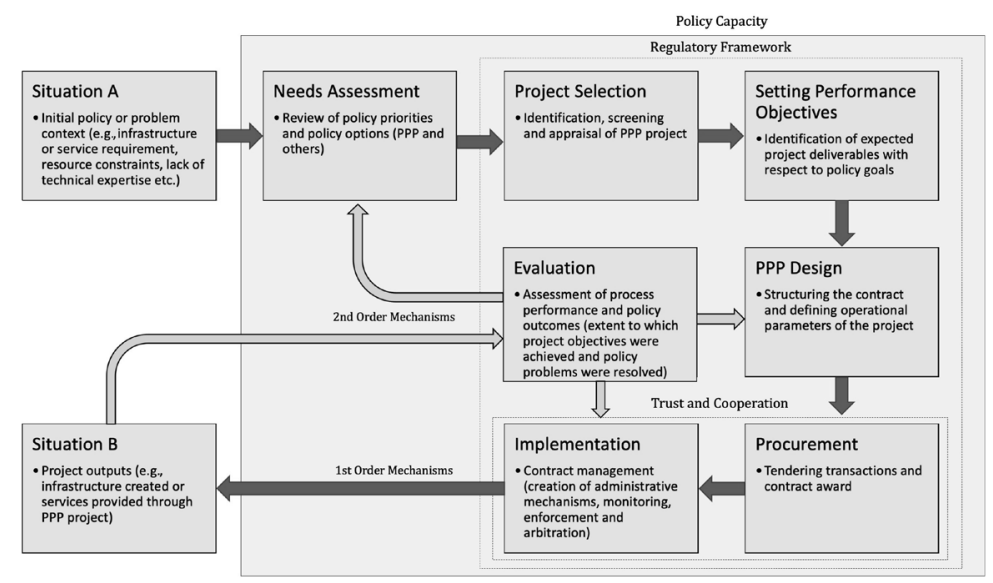

Figure 5.2 A model of causal mechanisms in PPP policy

or minimal efficiency gains and produce undesirable outcomes (e.g., reduced government control and discriminatory access) (Crowe, 1998; Fourie and Burger, 2000). Figure 5.2 presents a simplified causal model to help identify various elements in the PPP cycle that affect outcomes. What follows is a reflection on the levers that policy-makers can modulate to channel causal interactions in the desired direction.

\subsection{Performance Goals}

It is common for governments to not explicitly outline the objectives of PPP projects. Failure to agree on what constitutes success can cause partners to work at cross-purposes and lead to accountability problems (Teisman and Klijn, 2001, 2002; Hodge and Greve, 2010, 2011). It is important to align the performance objectives of PPP projects with their larger policy goals (Trivedi, 1989; Yuan et al., 2009) and to recognize that PPP goals are primarily social-centric. Notions of performance must therefore encompass the expectations of citizens, and display traits that citizens naturally expect from providers of public services in terms of equitable access, democratic accountability, oversight and recourse to grievance redress (Behn, 1998, 2001; Watson, 2003).

\subsection{Contract Design, Trust and Cooperation}

The partnership agreement or contract provides the legal foundations for the partnership and specifies the operational triggers that activate the causal 
interactions that determine PPP outcomes. It typically spells out the objectives of the partnership, the modus operandi through which the project will achieve the objectives, the rights and obligations of each partner, the risk-sharing arrangement, the manner in which performance will be ascertained, the system for handing rewards and penalties, and the process through which disputes will be addressed, adjudicated and remedied.

PPPs can potentially lead to loss of government control over the quantum, quality and accessibility of services provided (as some anecdotal experiences show), unless these aspects are clearly incorporated in the contract (De Bettignies and Ross, 2004). Yet, literature on the theory of contracts suggests that most contracts in the real world are simple and inherently incomplete (Hart and Moore, 1988, 1999; Tirole, 1999; Eggleston, Posner and Zeckhauser, 2000). It is practically impossible to specify all contingencies in a contract, due to cognitive limitations, lack of full information, and prohibitive costs involved in implementing and monitoring such contracts. Incomplete contracts create avenues for partners to engage in regulatory opportunism (Iossa and Martimort, 2009), and can lead risk-averse partners to underinvest, resulting in suboptimal outcomes (Grossman and Hart, 1986).

Task bundling (such as concession of both construction and operational control to a single private player) is one method to inhibit underinvestment by the private partner, when there are clear benefits that can be accrued in the long run from higher initial investments (Martimort and Pouyet, 2008). It also gives the government an alternative means to hold the private partner accountable if performance objectives are difficult to operationalize or measure (Hart, 2003). However, this can be challenging because service quality outcomes pertaining to complex service environments such as healthcare, are more difficult to measure and monitor than those for civic infrastructure projects like roads and airports or public utilities like water and electricity plants.

In such situations, the question of who holds ownership becomes important because ownership provides residual control in matters not directly addressed by the contract. Because governments have the primary welfare mandate, and ostensibly value policy objectives more than the private partner, it is imperative that ownership of public assets rest with the government (Besley and Ghatak, 2001; Iossa and Martimort, 2015). One exception might be partnerships with non-governmental organizations (NGOs), which, given their philanthropic character, might be at least as sympathetic to social justice considerations, and perhaps more committed than the government (Besley and Ghatak, 2001).

These issues highlight the pitfalls of a purely transactional approach to contract design. The test of a good contract is its ability to keep stakeholder interests aligned (Evans and Bowman, 2005; Ni, 2012). This often requires contracts to be renegotiated from time to time, in light of new information and experiential learning (relational contracting). Therefore, while being as 
explicit as possible, contracts must offer sufficient flexibility to allow for the management of unanticipated risks, fluctuations in the environment and other externalities. Such ongoing management requires trust and cooperation among partners to keep them engaged in long-term collaborative behaviour that is mutually beneficial (Darwin, Duberley and Johnson, 2000).

\subsection{Regulatory Infrastructure and Policy Capacity}

One of the ironies that Fourie and Burger (2000) point to in their economic analysis of PPPs is that while governments frequently cite their lack of management capacity as one of the reasons for involving the private sector through PPPs, they overlook the fact that designing good contracts and effectively managing partnerships require higher levels of capacity $(\mathrm{Wu}$, Ramesh and Howlett, 2015). Government officials often do not have the required knowledge or expertise to design effective partnerships, monitor and evaluate performance, and hold partners accountable (Ni, 2012). Policies meant to provide the regulatory framework for PPP projects are often vague and generic in their prescriptions, or simply non-existent. Such policies are necessary to clearly articulate the raisons d'être for PPPs, their sector-specific relevance, norms and processes for choice of projects and selection of partners, delivery standards, expected outcomes and governance structures. Istrate and Puentes (2011) and Casady (2016), for instance, have documented the positive effects of creating competencies within government departments to manage PPP processes in countries like Canada. Such initiatives can help in preventing second-order governance design failures, arising from the inability of policy-makers to effectively deploy what otherwise might be a perfectly sound instrument (Howlett and Ramesh, 2014). Regulatory and policy capacity are among the conditions necessary to catalyse the positive effects of PPPs, and therefore critical components in the mechanistic chain.

\section{PUBLIC-PRIVATE PARTNERSHIPS IN INDIA'S HEALTH SECTOR}

\subsection{Policy Background}

Since the onset of economic liberalization in 1991, India's policy-makers have used PPPs as one of the ways to overcome the challenges of its underfunded, poorly managed and largely overwhelmed public health system (HLEG, 2011). The general direction of government policy has seen a marked reduction in public expenditure on direct health infrastructure creation, and encouragement of private investment to bridge the gap. 
The central government and many state and local governments began to formally articulate plans and policies for promoting PPPs in the health sector during the 1990s (Bhat, 2000). Early attempts were limited to simple contracting out arrangements for ancillary services such as laundry, housekeeping and catering in public hospitals. In recent years, the private sector has been involved in providing outsourced diagnostic services, generic drugs and surgical products, rural obstetric services, and secondary and tertiary care under government-sponsored insurance programmes. In more close-knit arrangements, the government has engaged the private sector in the actual construction and management of public health infrastructure. Many state and local governments have formulated policies for the operation of dysfunctional public health facilities like Primary Health Centres (PHCs), diagnostic centres and secondary and tertiary hospitals, and for the creation of new health facilities by private players in return for financial incentives (Planning Commission, 2012).

Projects of this latter variety have been particularly prone to perverse provider behaviour, and in many cases have restricted public access to healthcare services. Nonetheless, PPPs continue to be a favoured policy approach for expanding public health services in underserved areas, particularly for secondary care (Planning Commission). The Niti Aayog (Policy Commission) has recently recommended the PPP model for the provision of medical services in cardiology, cancer and pulmonology by the private sector in select district hospitals in Tier 2 and Tier 3 cities.

\subsection{Policy Approach}

The government has taken a myopic view of PPPs. Their implementation illustrates many of the same design concerns mentioned earlier in this chapter. The problems are compounded by India's federal structure, which impedes coherent deployment. PPP projects are typically commissioned by state and local governments based on their respective priorities, service requirements, fiscal conditions and political considerations. Only about a third of all projects are implemented by the central government (Hans, 2017).

In the health sector, the National Health Mission (NHM) has identified PPPs as a supplementary strategy to achieve India's public health goals (MoHFW, 2013), but there is little clarity about what challenges are expected to be specifically addressed through their use (e.g., financing needs, staff shortages, lack of management expertise etc.), and how this intent is to be operationalized. In the absence of such details, most projects are fragmented standalone initiatives operating in policy silos, decoupled from macro sectoral policies, unsynchronized with other policy interventions, and unsupported by systematic evidence on their effectiveness. Case study evidence from some of the existing projects suggests that project objectives are seldom properly identified, expected utility 
is rarely assessed, norms for service delivery are weakly specified, implementation processes are non-transparent, and institutional capacity to manage and monitor contracts is limited (Bhat, 2000; Raman and Björkman, 2009).

Of late, exclusive policies for the implementation of PPPs have been formulated in some sectors (e.g., housing development). In other cases, PPPs have been incorporated within existing sector strategies for developing certain classes of infrastructure (e.g., Metro rail projects). However, most PPP projects still operate outside the purview of any formal policy or governing institution (Hans, 2017). A National PPP Policy was drafted as a guiding framework in 2011 but is yet to be enacted (DEA, 2011). Efforts have mainly focused on the following elements: (1) provision of financial support to encourage private investment in public infrastructure development; (2) creation of fast-track appraisal and approval procedures; (3) guidelines for vetting project proposals, and for awarding and implementing contracts; and (4) state-level capacity building through training, technical assistance and the creation of PPP Cells (DEA, 2017). While the actual status of these initiatives is unclear and beyond the scope of this chapter, there are clearly attempts being made to streamline PPP processes, optimize outcomes (in terms of cost savings, fresh expertise and new technologies), and promote accountability by curbing the inclination of state governments to enter into ad hoc concessionary arrangements without competitive bidding.

However, this approach fails to connect process strengthening efforts to the big picture. Its emphasis is lopsidedly on creating a business-friendly investment climate, reducing transaction costs and incorporating global best practices in procurement, all of which, while critical, are not sufficient for policy success. There is acknowledgement of the need to ensure that projects benefit end users, but this concern is not reflected in policy design or in the norms for appraisal and evaluation, which is contrary to design logic.

In addition, current policies are oriented towards hard infrastructure projects where the rationale for PPPs is easier to justify, objectives are well defined and assessments more straightforward, as against soft service projects where the policy goals are nebulous and their linkage with stated deliverables is unclear. Recommended templates for social sector PPPs such as hospitals, diagnostic centres and medical colleges are fairly generic with no sector-specific guidelines or policy inputs. ${ }^{2}$

Last, there is no unified authority or coordinated interagency mechanism for the regulation of PPPs in the new framework. The nodal agency in many states is an Infrastructure Development Board or PPP Cell that has technical competence to oversee procurement and contract management processes, but little sectoral expertise. For substantive regulation of core PPP activities (e.g., healthcare delivery, medical education etc.), projects are subject to sector-specific or issue-specific line agencies (e.g., State Departments of 
Health, Medical Councils etc.) that have limited mandates and little expertise in designing and managing PPP projects. Such fragmentation of authority impairs the effective deployment of PPPs as a health sector strategy. Mahalingam, Devkar and Kalidindi (2011) have found similar coordination issues in water and sanitation projects, which indicates a problem with the general policy approach to PPPs, rather than a sector-specific issue.

\subsection{Three Cases of Design Failure}

We briefly examine the experience of three PPP projects that deal with the provision of hospital-based secondary and tertiary care services in three Indian states: Maharashtra, Karnataka and the National Capital Territory of Delhi. The cases involve different contracting arrangements and a range of concessionary benefits. Because there are no standardized evaluations, and because the original sources are wide-ranging in the type and quality of information they provide, there are some differences in the different aspects discussed across the three cases.

\subsubsection{SWAN Municipal General Hospital ${ }^{3}$}

The SWAN Municipal General Hospital project in Mumbai (Maharashtra) was conceived by the Privatization Initiative Cell of the Municipal Corporation of Greater Mumbai (MCGM) as a part of its campaign for redeveloping dilapidating civic amenities, including government peripheral hospitals and maternity homes, through PPPs. Given the high cost of setting up new infrastructure and upgrading existing facilities, the government had permitted private players to develop such amenities, in return for floor space (Urban Development Department, 1991; Privatization Initiative Cell, 2000). This allowed the government to develop public facilities without the need to acquire land under private ownership and any additional financial burden. The prime real estate locations of public hospitals were crucial considerations in the government's decision.

SWAN Hospital was the first government health facility that was brought under this new regime. It was originally an 86-bed maternity hospital used for obstetric care by women from the nearby slums. By the mid-1990s, its bed strength had reduced significantly due to negligence and lack of public funding. A state-owned power company (SWAN) offered to upgrade the hospital to a 100-bed secondary care hospital, in return for subsidized healthcare for its employees. Because the government was unable to meet the operational costs once the new facility was constructed, a charitable trust (CT) was brought in after a cursory review of experienced NGOs for operating the facility on caretaker and no-profit-no-loss basis for 30 years under a tripartite agreement in 2002. The allotment of prime land without lease rent reduced the CT's capital expenditure and shortened the project's gestation period. The CT also 
received tax benefits and subsidies from the government and was permitted to build additional infrastructure and provide new medical specialities to private clients. In return, it was required to reserve 40 per cent outpatient and 33 per cent inpatient facilities for poor patients and provide them selected medical services at nominal charges set by the government. Patients were required to pay higher private charges for accessing services not covered by the agreement.

The effective quantum of services for poor patients was grossly deficient. ${ }^{4}$ Many in the surrounding communities were unaware of their entitlements and reported experiencing stringent gatekeeping by the security staff. There have been allegations of malpractice, overcharging, denial of care and non-adherence to prescribed allocations. Government authorities occasionally cautioned the hospital, and issues were often settled through negotiation but with little long-term resolution. Since certain clauses in the agreement were ambiguous and lent themselves to different interpretations, and also because service obligations were fairly limited in scope, the lacunae allowed the service provider to argue that reservation targets had been consistently met, even though healthcare access for the general population had clearly declined. The government had little supervisory control over hospital operations and no effective mechanism for addressing patient grievances. This encouraged a system of political patronage and conflict, creating avenues for local politicians to get involved in routine administrative matters and pressure the management in ways that were obtrusive and inimical to the smooth functioning of the hospital.

After over a decade's partnership, the government issued an eviction notice to the hospital in 2014 for violating structural norms and for denying care to patients, which was legally challenged. The notice was later withdrawn and the issue was mutually settled out of court.

\subsubsection{Rajiv Gandhi Super-Speciality Hospital ${ }^{5}$}

The 350-bed Rajiv Gandhi Super-Speciality Hospital (RGSH) in Raichur (Karnataka) was set up as a joint venture of the Government of Karnataka and the Apollo Hospitals Enterprise Limited (AHEL), a public listed company that owns and operates a chain of hospitals, clinics, diagnostic centres and pharmacies. It was initiated with seed funding from the Organization of Petroleum Exporting Countries (OPEC) with the objective of providing quality super-speciality services at low cost to people in northern Karnataka. The government began construction in 1997, and unsuccessfully tried to operate the hospital for a year before deciding to invite a non-profit private sector organization for managing the hospital. A service agreement was signed in 2001 between the Department of Health and Family Welfare (DHFW) and Apollo Hospitals to run the hospital for an initial period of ten years. 
The government made huge capital investments in the form of land, hospital buildings, medical equipment, and infrastructure such as roads, power, water and other utilities while Apollo provided management expertise and personnel. Under the contract, Apollo was permitted to generate revenue from user fees and charges for medical services to patients above the poverty line. The government would reimburse all expenses incurred towards the provision of basic medical services to patients below the poverty line. It also agreed to compensate the anticipated losses for the first three years, to incentivize the service provider to start operations in the predominantly rural district and reduce the financial risks. Starting from the fourth year, Apollo was allowed to retain 30 per cent of the net profit. In case there were no profits in a given year, the government was required to pay a service charge of up to 3 per cent of the gross billing as payment for services. Apollo was responsible for all operational matters such as complying with medico-legal requirements, payment of utility tariffs and maintenance of hospital buildings.

An internal evaluation by the government concluded that the project had suboptimal outcomes and had failed to achieve the levels of utilization required to sustain operations. The hospital was unable to capitalize on government-sponsored insurance schemes to generate revenue and attain self-sufficiency. This was compounded by the failure of the government to fulfil its obligations for maintaining equipment and other civic facilities, as well as for the timely disbursement of funds. Shortage of medical equipment and specialists led to the suspension of some speciality services, forcing the hospital to curtail operations. Moreover, the operator's focus was on servicing paying clients. ${ }^{6}$ Average billing for patients below the poverty line was substantially higher than for others, and patients were coerced to pay at the point of service while the hospital fraudulently submitted insurance claims for reimbursement. The evaluation report also raised serious accountability concerns about equipment purchases and highlighted the failure of monitoring and redress mechanisms over the project's life cycle.

A change in the government post elections, led to a decision against renewing the contract or calling for fresh tenders. The partnership was terminated in 2012, and the hospital was later converted to a postgraduate teaching facility affiliated to a government medical college, in response to a long-term lobbying effort by medical education interest groups in the state.

\subsubsection{Indraprastha Apollo Hospital ${ }^{7}$}

The Indraprastha Apollo Hospital project was created through a joint venture between the Government of the National Capital Territory of Delhi (GNCTD) and the Apollo Hospital Group in 1988. The government provided land for the project on a 30-year renewable lease to Apollo starting in 1994 for a token annual payment, paid part of the expenditure for constructing the hospital 
building and provided equity capital. Apollo made the remaining required investments for building and medical equipment and assumed the role of operating the 600-bed super-speciality hospital.

As per the agreement, Apollo was entitled to all the revenue generated by the hospital, but responsible for the payment of operating expenses, repair costs, utility bills and taxes. In return, it was expected to provide speciality medical services specified in the contract (including medicines and diagnostic tests) free of cost to at least 30 per cent inpatients and 40 per cent outpatients who are poor and referred by the relevant government authority. The government was responsible for monitoring the implementation of the contract, and for inspecting the hospital to ensure that service obligations were met. Any disputes were to be resolved through discussion, and if necessary through arbitration.

The PPP has been hugely successful from Apollo's perspective in terms of commercial viability and profits. The group's flagship hospital has expanded through its network of secondary catchment facilities in the region. It has been consistently featured among the country's best-ranked hospitals and top accredited destinations for medical tourism and won numerous awards for quality of care and clinical excellence. At the same time, the project has faced accusations of high hospital tariffs, non-compliance with contractual commitments, failure to provide information to the public about its obligations and procedures to make benefits available, arduous referral procedures making access difficult, and overcharging for patients eligible for free treatment. There have been several public interest litigations on these violations, and the hospital is found to have been perennially in breach of contract (High Court of Delhi, 2009; CIC, 2015). ${ }^{8}$ Notwithstanding the legal directives, compliance remains a problem. The project lacks an effective monitoring framework and the government is widely recognized to have failed in reining in the private partner and in taking corrective action against violations. Despite providing major funding in the formative stages, and holding a 26 per cent stake in the project, the government has ineffectual representation on the Board of Directors and little say in governance. There is also potential conflict of interest because the government holds part equity and is thus a concessionaire subject to supervision, but at the same time tasked with supervisory responsibilities as the public authority. This inherently creates a regulatory dilemma.

\subsection{Leveraging Partnership Mechanisms for Policy Success}

While many reasons are offered in support of employing PPPs, they often boil down to limited capacity of the government. It is assumed that PPPs will help overcome the government's limitations by leveraging private sector capacities to achieve policy objectives. While they are occasionally effective, such expectations are often not borne out by experience. The presented cases 
demonstrate how PPPs can fail to live up to expectations and aggravate rather than ameliorate problems. The argument here is not that PPPs are inherently ineffective instruments but rather that they require specific conditions to be effective. The three case studies highlight some of the common reasons for their failure and identify the conditions under which they can be expected to be more effective.

As alluded to below, policy failure can occur from weaknesses at any step in the policy process. In the cases shown in Table 5.1, failures occurred at multiple levels: (1) failure to clearly identify the policy goals (goal ambiguity); (2) failure to ascertain if PPPs were appropriate to achieve the goals, and if there were better alternatives (instrument mismatch); (3) failure to design incentive compatible contracting arrangements (poor calibration); (4) failure to effectively implement contracts and manage partnerships (weak deployment); and (5) failure to draw experiential lessons for making policy corrections and continual design improvements (non-learning). These process failures were nested within (and catalysed by) larger institutional weaknesses in policy capacity, regulation, and interorganizational trust and cooperation.

It is not surprising therefore that India's healthcare PPPs have produced mostly poor results. Indeed, it is unclear what concrete outcomes policy-makers seek to achieve through PPPs (beyond generic pronouncements of good healthcare for all) and how they intend to get there. Most PPP projects are currently operating under ambiguous (or in the absence of any) policy directives. The policy framework is geared towards harnessing the investment potential and operational proficiencies of the private sector via PPPs without a consideration of their relative utility in helping the government achieve welfare objectives. As a result, the operational emphasis is on strengthening procurement processes and encouraging the private sector (process considerations), rather than on aligning incentives such that the pursuit of underlying profit motives leads to outcomes that are consistent with public sector goals (programmatic considerations) (Marsh and McConnell, 2010). Without a concerted effort to understand PPP mechanisms and create a conducive institutional environment, it is conceivable that PPPs might lead to more efficient outcomes, productivity improvements and enhancements in systemic capacity, but not necessarily in ways that serve public interest.

The cases also underscore the importance of transparent, unambiguous and explicit language in the operationalization of contract provisions. Uncertainties provide an avenue for stakeholders to use discretion to interpret provisions, in a manner that is self-serving but unfavourable for the partnership. The ambiguity on reservation provisions in the contract for the SWAN Municipal General Hospital is a case in point. Also important is the creation of capacity within the government to design and implement contracts, and monitor compliance, and the institution of effective systems through which accountability can be 
Table 5.1 Levels of PPP failure

\begin{tabular}{|c|c|c|}
\hline Project & Issues & Level of Failure \\
\hline \multirow{14}{*}{$\begin{array}{l}\text { SWAN Municipal General } \\
\text { Hospital }\end{array}$} & Ad hoc decision-making & $\begin{array}{l}\text { Goal definition, instrument } \\
\text { selection, learning }\end{array}$ \\
\hline & Narrow coverage & Calibration, learning \\
\hline & Contract ambiguity & \\
\hline & Weak monitoring and remedial & \\
\hline & framework & \\
\hline & Lack of effective government & \\
\hline & involvement in project & \\
\hline & governance & \\
\hline & Non-competitive procurement & Implementation, learning \\
\hline & Limited public access to & \\
\hline & information & \\
\hline & Gatekeeping and denial of care & \\
\hline & Unethical hospital practices & \\
\hline & Political interference & \\
\hline \multirow{11}{*}{$\begin{array}{l}\text { Rajiv Gandhi Super-Speciality } \\
\text { Hospital }\end{array}$} & Ad hoc decision-making & $\begin{array}{l}\text { Goal definition, instrument } \\
\text { selection, learning }\end{array}$ \\
\hline & $\begin{array}{l}\text { Poor specification of service } \\
\text { deliverables }\end{array}$ & Calibration, learning \\
\hline & Misaligned incentive structure & \\
\hline & Weak monitoring and remedial & \\
\hline & framework & \\
\hline & Lack of effective government & \\
\hline & involvement in project & \\
\hline & governance & \\
\hline & Operational inefficiency & Implementation, learning \\
\hline & Unethical hospital practices & \\
\hline & Government default on payment & \\
\hline \multirow{11}{*}{ Indraprastha Apollo Hospital } & & \\
\hline & Misaligned incentive structure & Calibration, learning \\
\hline & Weak monitoring and remedial & \\
\hline & framework & \\
\hline & Lack of effective government & \\
\hline & involvement in project & \\
\hline & governance & \\
\hline & $\begin{array}{l}\text { Limited public access to } \\
\text { information }\end{array}$ & Implementation, learning \\
\hline & Gatekeeping and denial of care & \\
\hline & Unethical hospital & \\
\hline & practices & \\
\hline
\end{tabular}


exercised. These were major issues in all three cases, which ensured that only minimal public sector gains were achieved.

There are also reasons to question some common assumptions behind the advocacy for PPPs. First, both the Rajiv Gandhi Super-Speciality Hospital and the Indraprastha Apollo Hospital projects saw massive financial investments by the respective state governments even though lack of funds is a commonly cited reason for PPPs. ${ }^{9}$ The cases show that governments are often capable of making upfront investments, committing long-term financial resources and providing considerable subsidies (foregone revenue) to PPP projects, so their motivations for entering into partnership arrangements may be other than the need for private capital (Hart, 2003). However, in both cases, the governments' financial contributions were disproportionately higher than the welfare returns realized on the investments. In fact, in all three cases, the contracts reduced governmental control and legally restricted access to free or subsidized services to a narrow band of citizens deemed eligible based on unreasonable economic criteria, contingent on their ability to prove their eligibility at the point of care, and subject to arbitrarily determined caps on reservation. Second, the proposition that partnerships with NGOs for social projects are likely to be more successful is refuted by the case of the SWAN Municipal General Hospital (Besley and Ghatak, 2001). Getting the contract right is critical even when the private partner is ostensibly committed to social welfare. Last, in the case of the Rajiv Gandhi Super-Speciality Hospital project, there were negligible, if any, efficiency gains from the partnership. In fact, the project outcomes were suboptimal, suggesting that private sector involvement by itself does not lead to improvements in efficiency. Promoting efficiency requires thoughtful design and deliberate effort.

Together, the cases call for a cautious approach in determining when and under what conditions PPPs are likely to produce effective results. A nuanced understanding of the pathways through which they operate and interact with the policy environment is necessary to harness their potential as policy instruments and prevent counterproductive policy effects.

\section{NOTES}

1. Research for this project was funded by the Lee Kuan Yew School of Public Policy, National University of Singapore.

2. For instance, the draft policy suggests the adoption of the annuity-based build-operate-transfer (BOT) model for PPPs in the social sector, because cost recovery through user fees may be difficult and economic returns are less assured, but there is little clarity on how economic evaluations are to be carried out, or how value for money (VfM) is to be ascertained, given the social nature of the goods in question.

3. The empirical data and narrative is drawn from Bisht and Virani (2016) and background materials used in their study, including the contract agreement and general media report- 
age. The hospital's identity and that of other parties in the contract was masked in the original study to preserve anonymity. The same naming convention is followed here.

4. For instance, while the array of medical specialities in the hospital went up significantly, the number of beds available for the general population out of the total 100 -odd was less than 30 , of which a mere six were reserved for obstetric care.

5. Information for this case is derived from DHFW (2011), Karpagam et al. (2013), KPMG (undated), Raman and Björkman (2009) and general media reportage.

6. Only 11 per cent of functional beds were allocated for the treatment of poor patients. Their numbers as a proportion of total patients declined from 95 per cent to 21 per cent for inpatient services and from 93 per cent to 8 per cent for outpatients over ten years.

7. The case draws on information from the following sources: Anon (undated); CIC (2015); High Court of Delhi (2009); Lefebvre (2010); Sama (2012) and Thomas and Krishnan (2010).

8. Only 140 out of the total 650 hospital beds were allocated for free treatment (considerably less than the stipulated one-third). Of these, only about 20 beds were occupied at any given time because the hospital charged patients for all medicines and consumables, making it unaffordable.

9. Raman and Björkman (2009) found the Rajiv Gandhi Super-Speciality Hospital project to be one of the most expensive from among the several PPP projects they analysed.

\section{REFERENCES}

Anon (undated), Case Study, Urban Health: Indraprastha Apollo Hospital, New Delhi, accessed 15 October 2018 at http://idd.kar.nic.in/docs/CS_Appollo.pdf.

Baru, R.V. and M. Nundy (2008), 'Blurring of boundaries: Public-private partnerships in health services in India', Economic and Political Weekly, 43(4), 62-71.

Behn, R.D. (1998), 'The new public management paradigm and the search for democratic accountability', International Public Management Journal, 1(2), 131-64.

Behn, R.D. (2001), Rethinking Democratic Accountability, Washington, DC: Brookings Institution Press.

Besley, T. and M. Ghatak (2001), 'Government versus private ownership of public goods', The Quarterly Journal of Economics, 116(4), 1343-72.

Bhat, R. (2000), 'Issues in health: Public-private partnership', Economic and Political Weekly, 35(52/53), 4706-16.

Bisht, R. and A. Virani (2016), 'Globalization and the health of a megacity: The case of Mumbai', in S. Hodges and M. Ra (eds), Public Health and Private Wealth: Stem Cells, Surrogates and Other Strategic Bodies, New Delhi: Oxford University Pres, pp. 99-120.

Boase, J.P. (2000), 'Beyond government? The appeal of public-private partnerships', Canadian Public Administration, 43(1), 75-92.

Borins, S. (1995), 'The new public management is here to stay', Canadian Public Administration, 38(1), 122-32. 
Casady, C. (2016), 'PPP procurement in Canada: An analysis of tendering periods', PAM Honors Thesis, Department of Policy Analysis and Management, Cornell University.

CIC (2015), Ruling on Complaint by Shri M.K. Gandhi vs Indraprastha Apollo Hospital, New Delhi, File No. CIC/SA/C/2014/000273, Central Information Commission, accessed 15 October 2018 at https://ciconline.nic .in/cic_decisions/CIC_SA_C_2014_000273_M_146012.pdf.

Crowe, S. (1998), 'Public-private partnerships - business as usual?', The Lancet, 352(9123), 212.

Daniels, R.J. and M.J. Trebilcock (1996), 'Private provision of public infrastructure: An organizational analysis of the next privatization frontier', The University of Toronto Law Journal, 46(3), 375-426.

Darwin, J., J. Duberley and P. Johnson (2000), 'Contracting in ten English local authorities: Preferences and practices', International Journal of Public Sector Management, 13(1), 38-57.

De Bettignies, J.E. and T.W. Ross (2004), 'The economics of public-private partnerships', Canadian Public Policy/Analyse de Politiques, 30(2), 135-54.

DEA (Department of Economic Affairs) (2011), National Public Private Partnership Policy, Draft for Consultation, New Delhi: Ministry of Finance, Government of India.

DEA (Department of Economic Affairs) (2017), Public Private Partnerships in India, official website of the PPP Cell, Infrastructure Division, Department of Economic Affairs, Ministry of Finance, Government of India, accessed 10 January 2017 at https://www.pppinindia.gov.in.

DHFW (Department of Health and Family Welfare) (2011), Rajiv Gandhi Super-Speciality Hospital, Raichur: Review of the PPP Project, Bangalore: Department of Health and Family Welfare, Government of Karnataka, and Karnataka State Health System Resource Centre.

Eggleston, K., E.A. Posner and R.J. Zeckhauser (2000), 'Simplicity and complexity in contracts', John M. Olin Program in Law and Economics Working Paper No. 93, University of Chicago Law School.

Evans, J. and D. Bowman (2005), 'Getting the contract right', in G. Hodge and C. Greve (eds), The Challenge of Public-Private Partnerships: Learning from International Experience, Cheltenham, UK and Northampton, MA, USA: Edward Elgar Publishing, pp. 62-80.

Fourie, F. and P. Burger (2000), 'An economic analysis and assessment of public-private partnerships (PPPs)', South African Journal of Economics, 68(4), 305-16.

Fritzen, S. (2007), 'Crafting performance measurement systems to reduce corruption risks in complex organizations: The case of the World Bank', Measuring Business Excellence, 11(4), 23-32. 
Grossman, S.J. and O.D. Hart (1986), 'The costs and benefits of ownership: A theory of vertical and lateral integration', Journal of Political Economy, 94(4), 691-719.

Hans, A. (2017), 'Rebooting public-private partnership in India', NITI Aayog, accessed 10 January 2017 at http://niti.gov.in/content/rebooting -Public-Private-partnership-india.

Hart, O. (2003), 'Incomplete contracts and public ownership: Remarks, and an application to public-private partnerships', The Economic Journal, 113(486), C69-C76.

Hart, O. and J. Moore (1988), 'Incomplete contracts and renegotiation', Econometrica: Journal of the Econometric Society, 56(4), 755-85.

Hart, O. and J. Moore (1999), 'Foundations of incomplete contracts', The Review of Economic Studies, 66(1), 115-38.

High Court of Delhi (2009), Judgment of the Honourable High Court of Delhi, All India Lawyers Union (Delhi Unit) vs Govt. of NCT of Delhi and Others, WP(C) No. 5410/1997, accessed 10 January 2017 at https://indiankanoon .org/doc/185064409/.

HLEG (2011), High Level Expert Group Report on Universal Health Coverage for India, submitted to the Planning Commission of India, New Delhi: High Level Expert Group on Universal Health Coverage.

Hodge, G. and C. Greve (2010), 'Public-private partnerships: Governance scheme or language game?', Australian Journal of Public Administration, 69(S1), S8-S22.

Hodge, G. and C. Greve (2011), 'Theorizing public-private partnership success: A market-based alternative to government?', paper presented at the Public Management Research Conference at Syracuse University, Syracuse, 2-4 June 2011, accessed 10 January 2017 at http://openarchive.cbs.dk/ bitstream/handle/10398/8573/Greve_2011_c.pdf?sequence=1.

Howlett, M. and M Ramesh (2014), 'The two orders of governance failure: Design mismatches and policy capacity issues in modern governance', Policy and Society, 33(4), 317-27.

Iossa, E. and D. Martimort (2009), 'The theory of incentives applied to the transport sector', accessed 10 January 2017 at http://dx.doi.org/10.2139/ssrn.1346884.

Iossa, E. and D. Martimort (2015), 'The simple microeconomics of publicprivate partnerships', Journal of Public Economic Theory, 17(1), 4-48.

Istrate, E. and R. Puentes (2011), Moving Forward on Public-Private Partnerships: US and International Experience with PPP Units, Brookings-Rockefeller Project on State and Metropolitan Innovation, accessed 10 January 2017 at https://www.brookings.edu/wp-content/ uploads/2016/06/1208_transportation_istrate_puentes.pdf. 
Karpagam, S., B. Roy, V.K. Seethappa and I. Qadeer (2013), 'Evidence-based planning - a myth or reality: Use of evidence by the Planning Commission on Public-Private Partnership (PPP)', Social Change, 42(2), 213-26.

KPMG (undated), Public-Private Partnerships in India, accessed 10 January 2017 at http://www.ibef.org/download/PublicPrivatePartnership.pdf.

Lefebvre, B. (2010), Hospital Chains in India: The Coming of Age?, Paris: Centre Asie, Institut Français des Relations Internationales.

Liu, X., D. Hotchkiss and S. Bose (2008), 'The effectiveness of contracting-out primary health care services in developing countries: A review of the evidence', Health Policy and Planning, 23, 1-13.

Lönnroth, K., M. Uplekar and L. Blanc (2006), 'Hard gains through soft contracts: Productive engagement of private providers in tuberculosis control', Bulletin of the World Health Organization, 84(11), 876-83.

Mahalingam, A., G.A. Devkar and S.N. Kalidindi (2011), 'A comparative analysis of public-private partnership (PPP) coordination agencies in India: What works and what doesn't', Public Works Management and Policy, 16(4), 341-72.

Marsh, D. and A. McConnell (2010), 'Towards a framework for establishing policy success', Public Administration, 88(2), 564-83.

Martimort, D. and J. Pouyet (2008), 'To build or not to build: Normative and positive theories of public-private partnerships', International Journal of Industrial Organization, 26(2), 393-411.

Maskin, E.S. (2008), 'Mechanism design: How to implement social goals', The American Economic Review, 98(3), 567-76.

Mills, A. (1998), 'To contract or not to contract? Issues for low and middle income countries', Health Policy and Planning, 13(1), 32-40.

MoHFW (Ministry of Health and Family Welfare) (2013), Framework for Implementation: National Health Mission (2012-2017), New Delhi: Ministry of Health and Family Welfare, Government of India.

Moe, R.C. (1994), 'The "reinventing government" exercise: Misinterpreting the problem, misjudging the consequences', Public Administration Review, 52(2), 111-22.

Morgan, K.J. and A.L. Campbell (2011), The Delegated Welfare State: Medicare, Markets, and the Governance of Social Policy, Oxford: Oxford University Press.

Ni, A.Y. (2012), 'The risk-averting game of transport public-private partnership: Lessons from the adventure of California's State Route 91 Express Lanes', Public Performance and Management Review, 36(2), 253-74.

Planning Commission (2012), Twelfth Five-Year Plan (2012-2017), Social Sectors, New Delhi: Planning Commission, Government of India.

Privatization Initiative Cell (2000), Guidelines, Mumbai: Municipal Corporation of Greater Mumbai. 
Raman, A.V. and J.W. Björkman (2009), Public-Private Partnerships in Health Care in India: Lessons for Developing Countries, London: Routledge. Sama (2012), Free Treatment in the Private Sector: Myth or Reality? A Pilot Study of Private Hospitals in Delhi, New Delhi: Sama, Resource Group for Women and Health.

Teisman, G. and E.-H. Klijn (2001), 'Public-private partnerships in the European Union: Official suspect, embraced in daily practice', in S. Osborne (ed.), Public-Private Partnerships: Theory and Practice in International Perspective, New York: Routledge, pp. 165-86.

Teisman, G. and E.-H. Klijn (2002). 'Partnership arrangements: Governmental rhetoric or governance scheme?', Public Administration Review, 62(2), 197-205.

Thomas, G. and S. Krishnan (2010), 'Effective public-private partnership in healthcare: Apollo as a cautionary tale', Indian Journal of Medical Ethics, 7(1), 2-4.

Tirole, J. (1999), 'Incomplete contracts: Where do we stand?', Econometrica, 67(4), 741-81.

Trivedi, P. (1989), 'Performance evaluation system for memoranda of understanding', Economic and Political Weekly, 24(21), M55-M59.

Urban Development Department (1991), Development Control Regulations for Greater Mumbai 1991, Mumbai: Government of Maharashtra.

Vining, A.R. and D.L. Weimer (2016), 'The challenges of fractionalized property rights in public-private hybrid organizations: The good, the bad, and the ugly', Regulation and Governance, 10(2), 161-78.

Watson, D. (2003), 'The rise and rise of public-private partnerships: Challenges for public accountability', Australian Accounting Review, 13(31), 2-14.

World Bank Group (2014), Public-Private-Partnership Legal Resource Center, website, accessed 10 January 2017 at https://ppp.worldbank.org/ public-private-partnership/.

Wu, X., M Ramesh and M. Howlett (2015), 'Policy capacity: A conceptual framework for understanding policy competences and capabilities', Policy and Society, 34(3), 165-71.

Yuan, J., A.Y. Zeng, M.J. Skibniewski and Q. Li (2009), 'Selection of performance objectives and key performance indicators in public-private partnership projects to achieve value for money', Construction Management and Economics, 27(3), 253-70. 